\title{
Comment
}

Cold Spring Harb Symp Quant Biol 80 (2015) doi: 10.1101/sqb.2015.80.027318

\section{Publisher's Comment}

A reader raised the issue of similarity between this Cold Spring Harbor Symposia on Quantititive Biology (SQB) review:

Bernardi G. 2015. Genome organization and chromosome architecture. Cold Spring Harb Symp Quant Biol. Published in Advance January 22, 2016, doi: 10.1101/sqb.2015.80.027318

and an article published by PLoS One in November 2015:

Bernardi G. 2015. Genome organization and chromosome architecture. PLoS One 10: e0143739. doi: 10.1371/ journal.pone.0143739.

There is some overlap in content between the two publications; however, there are also differences in focus and scope. While the PLOS submission was under consideration, Professor Bernardi informed PLOS of his intention to publish another manuscript in SQB that put the work in a larger perspective. Professor Bernardi informed the publisher of SQB of the article submitted to PLoS One, he cited the PLoS One article, and he attributed the reproduced figures to the PLoS One article in the figure legends.

doi: $10.1101 / \mathrm{sqb} .2015 .80 .030197$ 


\section{$\$_{\mathrm{CSH}}^{\infty}$ Cold Spring Harbor Symposia SYMPOSIA On Quantitative Biology}

\section{Publisher's Comment}

Cold Spring Harb Symp Quant Biol 2015 80: originally published online April 28, 2016 Access the most recent version at doi:10.1101/sqb.2015.80.030197

Related Content Genome Organization and Chromosome Architecture

Giorgio Bernardi

Cold Spring Harb Symp Quant Biol UNKNOWN , 2015 80: 83-91

License

Email Alerting Receive free email alerts when new articles cite this article - sign up in Service the box at the top right corner of the article or click here. 